\title{
A REVIEW PAPER ON FOOD SECURITY
}

\section{ANSUMANSAMAL \& BIBHUTI B PRADHAN}

Department Of Management, Siksha 'O’ Anusandhan (Deemed To Be University), Bhubaneswar, Odisha

\begin{abstract}
Food security, as a rule, is progressively influenced by worldwide monetary and natural marvels. Under this, the food costs are influenced because of food shortage which causes social and political precariousness, and can raise helpful emergency. In this setting it is smarter to examine the meaning of food security given by the Rome Declaration on World Food Security at the World Food Summit, held in 1996. Here the scientists needed to comprehend the effect of Food security w.r.t. a global concern."On similar rules India's activities to guarantee food security for its citizens ranges from coordinated endeavors to help rural creation to far-running business sector mediations focused on value adjustment. Measures have been acquainted to improve the entrance to food of the destitute individuals through open appropriation and salary producing plans. (A portion of the plans have been featured in the paper.) The issue of underinvestment in farming similarly as the status of India w.r.t. world is exacerbated during monetary unrest, since when both private and open spending plans contract, speculations will in general be sliced to a more prominent degree than different uses in all segments - including agribusiness. In attempting to adapt to the weight of back to back Food and monetary emergencies certain advances in the zone of bio-nanotechnology would go far in helping Food security. Bio-nanotechnology will take horticulture from the period of hereditarily adjusted (GM) harvests to the state-of-the-art existence of molecularly changed living beings. This paper is separated into three sections and manages applied survey, real factors government measures and at long last advancements towards Food security.
\end{abstract}

KEYWORDS: Bio-Nanotechnology, Food Security and Government Measures

Received: Jun 08, 2020; Accepted: Jun 28, 2020; Published: Aug 27, 2020; Paper Id.: IJMPERDJUN2020913

\section{INTRODUCTION}

The philanthropic perspective on food security is as celestial and moral as the mankind is...! This is on the grounds that people as a whole put stock in God, even the financial specialists acknowledges that the age of the food from the land is a, free endowment of nature ${ }^{e e}$ for example God. Along these lines, at whatever point the issue of food comes to conversation it has constantly a moral side to examine, aside from business see.

Here in this paper, the scientists have broken down a situational possibilities w.r.t. the number of inhabitants in India versus Food creation, the accessibility of Food to this populace simultaneously access to the Food stock and its upkeep (for example to protect its sustenance esteem. Simultaneously, people might want to pull in the consideration of the peruser to the issue of "Food too it's Security" ought to be considered as a Global issue too. The way of thinking behind this idea resembles this. Consider a situation where the creation of food is less in a specific nation; by and large the rates are raised up for the period. Simultaneously it offers ascend to an open door for those nations where the creation of food is increasing. Here the rates drops and again a danger to the makers for example the ranchers. This circumstance prompts unsteadiness too beginning of business exchanges[1]-[3]. 
The word "Food Security" itself has gone under extreme progress in order to genuine Food Security also. Consider the meaning of Food Security given by -

At the World Food Summit 1974 Food security is characterized as, "Accessibility consistently of sufficient world Food supplies of fundamental groceries to support a consistent development of Food utilization and to counterbalance variances underway and costs".

In 1983, FAO - "Guaranteeing that all individuals consistently have both physical and financial access to the fundamental Food that they need." World Bank in 1986 - "The entrance by all individuals consistently to enough Food for a functioning and solid life."

In 1996, World Food Summit re-imagined the meaning of Food security as, "Food security exists when all individuals, consistently, have physical and financial access to adequate, sheltered and nutritious Food to meet their dietary needs and Food inclinations for a functioning and sound way of life".

In 2002 once more, FAO Expert Consultation on Food Security gave a working meaning of Food security as, "Food security exists when all individuals, consistently, have physical, social and financial access to adequate, sheltered and nutritious Food which meets their dietary needs and Food inclinations for a functioning and solid life."

From that point forward, a few definitions have been given by various associations, for example, the World Bank, Food and Agriculture Organization (FAO) and UNDP'es Human Development Report[4]-[6]. As a rule, Food security is characterized as, "financial access to Food alongside Food creation and Food accessibility." Food accessibility alone, thusly, doesn't guarantee Food security; access to Food is similarly significant.

A FAO report, August 2008, characterizes Food security as far as the accompanying four key angles:

- Food Availability - Sufficient accessibility of Food with the country through household creation, net imports (business or Food help) and persist of stocks.

- Food Access - Individual's ability to buy Food and to have the option to secure Food through wellbeing nets or accessibility.

- Food Utilization - Consumption of Food by the family unit $\mathrm{m}$ an appropriate structure. It additionally considers Food readiness, stockpiling and usage, sanitation, wholesome security and dietary equalization.

- Food Vulnerability-Vulnerability of the populace to Food frailty because of physiological, financial, social or political reasons.

Mulling over this we are currently in position to comprehend the worry of Food security with its authentic point of view and the real factors related with it. The instance of Food security is as essential to India all things considered for the remainder of the world. The researcher's fixation is looking into the issue relating to Indian point of view.

The first green upheaval in quite a while started in 1960s. It brought about expanding Food grain creation. It was the joined exertion of high return seeds, broad utilization of manures, land changes and water system conspires that brought about this wonderful accomplishment. Despite the fact that, it was sufficient to take care of everyone around 2,200 calories per day yet over the most recent ten years, India has added 150 million additional mouths to take care of simultaneously has expanded Food creation by just 15 million tons. 
INDIA, at present winds up amidst a confusing circumstance: endemic mass-hunger coinciding with the mounting Food grain stocks. The Food grain-stocks accessible with the Government remain at a record-breaking high of 62 million tons against a yearly prerequisite of around 20 million tons for guaranteeing Food security[7]-[9]. All things considered, an expected 200 million individuals are deprived and 50 million near the precarious edge of starvation, bringing about starvation passings. The Catch 22 lies in the intrinsic defects in the current strategy and execution bottlenecks.

To consider this incomprehensible circumstance a review was led. The discoveries of the overview report uncovers that the issue of Food security will be viewed as "Food frailty" and that to the urban piece of India. The nation has various sorts of issues w.r.t. Provincial and Urban part. M.S.Swaminathan Research Foundation and the World Food Program have drawn out a report on Food uncertainty in urban India. The hardship looked by family units with respect to tying down work just as access to pleasantries is the most noteworthy for those living in humble communities. This finding has a significant approach suggestion that projects planned for improving the day to day environments of the urban populace, particularly the urban poor.

Let us pose an Inquiry - How do families adapt to decreases in salary? At the point when families are confronted with expanded joblessness, declining compensation and decreased interest for their work, they will endeavor to keep up salary through movement or support in new kinds of monetary action. On the other hand, they will attempt to smooth utilization through selling resources, for example, domesticated animals, or getting when access to credit markets is doable. They will likewise adjust their spending designs by diminishing consumptions on sturdy merchandise the most and on Food the least. Food consumptions likewise move towards calorie-rich, vitality thick Foods (for example grains) and away from progressively costly protein-and supplement rich Foods.

\section{DISCUSSIONS}

\section{Real Factors - Government Measures}

The nations over the globe are seeing their economies slow and retreat. No country is resistant and, obviously, it is the least fortunate nations - and the most unfortunate individuals - that are enduring the most. Because of the monetary emergency, gauges detailed in this version of The State of Food Insecurity in the World show that, just because since 1970, more than one billion individuals - around 100 million more than a year ago and around one 6th of the entirety of mankind - are ravenous and undernourished around the world. The present emergency is generally phenomenal, with a few elements merging to make it harming to individuals in danger of Food instability. This will prompt a helpless circumstance. To comprehend this there are variables to be thought of.

Initially, it covers with a Food emergency which pushed the costs of essential staples past the compass of a great many needy individuals. The cost increments had constrained numerous poor families to sell resources or penance human services, instruction or Food just to remain above water. With their assets extended to limit, those families will think that it's hard to brave the financial tempest[10].

Second, with creating nations today more monetarily and industrially coordinated into the world economy than they were 20 years prior, they are unmistakably progressively presented to stuns in universal markets. This circumstance will plot not exclusively to separate business openings, yet in addition to diminish the cash accessible for government programs that are irreplaceable to advancing mechanical just as farming development. 
At this point it is an obvious sign of what the Food security implies? As indicated by the Food and Agriculture Organization at the United Nations, India has the biggest number of poor, Food uncertain individuals on the planet. Around 360 million individuals devour under $80 \%$ of their base vitality necessities, with ladies, youngsters, the country poor, lower-position, and innate populaces lopsidedly influenced. India might be one of the world's key developing economies, however it is winding up under expanding tension from Food security issues. It is additionally called attention to that around two-third of the country's occupants depend on cultivating as their primary wellspring of salary. The confusing circumstance lies here that, however there is expanding dependence of income of Indians relies upon farming as an occupation. This is because of a decrease in the accessibility of national water assets for rural purposes, deforestation and a lopsided rainstorm in July 2009. The subsequent decrease in crop yields is probably going to infuse inflationary weight into the economy, putting further strain on enormous areas of the people. These conditions, then, keep on declining as world Food costs increment. In light of direct meetings with individuals who are generally influenced by Food uncertainty, nation contextual investigations led by the World Food Program (WFP) remembered for its report give an understanding into how family units are influenced by the fall in settlements and different effects of the financial downturn. The contextual investigations likewise show how governments are reacting to the emergency by putting resources into agribusiness and system and growing wellbeing nets. These intercessions will assist with sparing lives and families, albeit given the seriousness of the emergency, substantially more should be finished.

Food security, along these lines, is an unpredictable issue influenced by a scope of variables including horticultural turn of events, limit, universal exchange streams, destitution and salary circulation, outside guide, just as macroeconomic strategies and government programs on sustenance and Food stronghold. Added to these are the effects of worldwide populace development and environmental change.

India's fundamental activities to guarantee Food security ranges from deliberate endeavors to help farming creation to far-extending market intercessions focused on both salary and value adjustment. One of the principal mediations by the Indian government was the death of the Essential Commodities Act in 1955 to shield the poor from the ideas of the market. The demonstration gave on the administration the ability to control creation, supply and appropriation of fundamental items to guarantee evenhanded dissemination of Food grains at reasonable costs.

With this there are measures acquainted with improve the entrance to Food of the poor through open dissemination (PD) and salary creating plans with the goal of making essential Food grains accessible to all at moderate costs. The Government has set up the Food Corporation of India (FCI)[3], [8]. The fundamental assignment of the FCI was a two overlay action. The main overlap was to acquire Food grains at Minimum Support Prices (MSP) and the subsequent overlay was to direct inventory so costs can be kept consistent over a period by building a cushion stock.

For a greater gather in coming years, various activities must be taken to the stale horticulture segment. These activities are focused on the working arrangements towards Food security issue. This activity could be three overlay:

- Use innovation together with more up to date development systems.

- Water the executives with collecting overabundance Monsoon water in the North and shipping it to the dry West and South.

- Guaranteeing a superior come back to the ranchers. 
Each conceivable move has been under Government of India's scanner. The last is worried about conceivable social change, should the majority go hungry...? The doing without isn't just a genuine test in India however a potential risk to China as well. Both the nations India and China while concentrating vigorously on industrialization have not focused on Food grains creation. This is the ideal opportunity for both the nations to investigate the issue all the more truly and to move center from unadulterated industrialization to horticulture as well.

\section{Advancements Towards Food Security}

Science and innovation developments have been key factors in accomplishing progresses in farming. Plant reproducing endeavors, joined with enhancements in agronomic practices have permitted us to stay up with populace development as far as giving a sufficient degree of Food supply. In any case, agribusiness needs to confront gigantic difficulties on numerous fronts and should assume a basic job in the improvement procedure with Bio-innovation for economical farming advancement.

Taking into account deteriorating Food grain creation and expanding utilization needs of the developing populace, the Government of India propelled a Centrally-supported plan, the „National Food Security Mission ${ }^{\text {ee }}$. Its significant target was to expand profitability of wheat, rice and heartbeats on a manageable premise in order to guarantee the country's Food security. The usage of the NFSM is required to build rice creation by 10 million tons, wheat by $8,000,000$ tons and heartbeats by 2,000,000 tons by 2011-12. This is likewise expected to make extra work openings. Accomplishing the national target of improving efficiency of simply the three yields (rice, wheat and heartbeats) is a test in front of us. Utilize and successful usage of existing and new innovation will be basic in efficiency enhancements, which is subject to enter costs, asset accessibility (soil wellbeing and water), ecological variables, showcase cost and others[9], [11].

\section{How Technology Will Help?}

Innovation is going to assume a significant job to take the grain creation from around 210 million tones today to 300 million tons by 2020 (for example 6\% expansion every year). This much Foodsupply is expected to take care of ,,the populace which by then will be around 1.4 billion imprint. Subsequently innovation needs to become fundamental part to convey higher Food grain supply needs. Innovation will assume its job in the accompanying manners:

- Agricultural info the board,

- $\quad$ Better seeds and development strategies.

\section{Beam of Hope}

Hereditarily Modified harvests (GM) will assume an essential job in future. It ought to be recalled that Dr. Norman Borlaug's built up the midget assortment wheat in Mexico, which was received in India and in this manner started the main green upheaval. Without receiving more up to date assortments of seeds and deductively arranged sources of info, it will be more enthusiastically to support Food grain yield. Obviously, the acquaintance of GM crops drove with foundation of biowellbeing standards in different countries, subsequently new items (plants, species and so on.) have been tried completely for their security. Throughout the entire existence of agribusiness, no item has ever been tried to this edge of security as bio-innovation items. It is on the grounds that legislatures, researchers, ranchers see the advantages of these advances which address creepy crawly resilience, herbicide resistance, and sickness resistance that an ever increasing number of nations are embracing them. This quick reception, in creating and the created world, has been the aftereffect of solid 
administrative components which are set up in these nations to evaluate the item and discharge the equivalent for shopper advantage.

Different methodologies including bio-nanotechnology can be taken for accomplishing the objectives of more harvest per drop of water, as water accessibility is anticipated to be one of the most critical imperatives on crop profitability. Dry spell evasion and dry season lenient harvests will secure yields significantly submerged worry just as underinvestment. Nitrogen and Phosphorous are two key composts for crop yield[4], [8].

Innovation that would permit diminished manure application to get present degrees of harvest yield has just been exhibited in field preliminaries in different pieces of the world. Utilization of this innovation would likewise have noteworthy effect on greenhouse gas discharges just as ground water quality. Because of decreased degrees of Nitrogen in nature; sending innovations which lessen item advancement cycles can fundamentally prompt better items quicker, creepy crawly and illness open minded harvests. Other than this post collect advances, stockpiling bugs and sicknesses can be adequately tended to by such sort of most recent Bio-innovative turns of events.

\section{Bio-Nanotechnology will Help India's Food Security}

Pastor for Food and Agriculture Sharad Pawar said at New Delhi on Wednesday nineteenth September 2009 talking at the debut meeting of the three-day Fifth Knowledge Millennium Summit on „B2B Bio and Nanotechnology“ sorted out by industry body Assocham that, "Advances in the region of bio-nanotechnology would go far in helping India's Food security, Bio-nanotechnology takes agribusiness from the time of hereditarily changed (GM) yields to the exciting modern lifestyle of molecularly altered life forms".

A rancher needs to turn into a section ,agronomiste and a section ,economist ${ }^{\text {ee }}$. He needs to rely on the data age to realize the climate design ahead of time (preceding planting crop), inputs like composts required for a specific harvest, bug control calendar to shield edit and expand advantage from the nearby water system plans. When the yield is reaped, the capacity and taking care of misfortunes are to be limited with cautious arranging and great neighborhood stockpiling. A rancher hosts to become get-together to the circulation system to forestall mal-appropriation and dealing with misfortunes.

Additionally Indian farming is intensely reliant on work, it isn't completely motorized. In spite of the fact that, tractor has gotten normal in India to furrow the fields, yet further automation until gathering is insufficient, of course it is because of underinvestment in agribusiness where there is one fundamental prerequisite which must be dealt with by giving access to credits at need rates.

Hence, the eventual fate of the innovation for expanding request and deficiencies or plausible deficiencies can be connected by the utilization of more up to date innovation, data science and changes the board rehearses.

\section{CONCLUSIONS}

Taking into account the above marvels the issue of food security is by all accounts a significant parameter for monetary soundness, humankind and also for taking care of things to come of living things. It requires triple exercises.

- Utilization of safe Genetically Modified yields and utilization of better Bio-mechanical seeds and pesticides.

- Recovery of desolate land into development with the less utilization of water assets, utilization of those harvests 
which requires less water as a prime source most definitely because of more weight of utilization of water originates from network supply for people (even at the expense of creation exercises).

- Utilization of expanding pay strategies by vital arranging of organization of characteristic assets, accessibility of money and in terms of professional career off of data innovation through respective arrangements with the assistance of Government.

\section{REFERENCES}

1. M. Qaim and S. Kouser, "Genetically Modified Crops and Food Security," PLoS One, 2013, doi: 10.1371/journal.pone.0064879.

2. R. Kalpana Sastry, H. B. Rashmi, and N. H. Rao, "Nanotechnology for enhancing food security in India," Food Policy, 2011, doi: 10.1016/j.foodpol.2010.10.012.

3. R. Lawford et al., "Basin perspectives on the Water-Energy-Food Security Nexus," Current Opinion in Environmental Sustainability. 2013, doi: 10.1016/j.cosust.2013.11.005.

4. P. S. Brahmanand et al., "Challenges to food security in India," Curr. Sci., 2013, doi: 10.9790/0837-194293100.

5. K. S. Varadharajan, T. Thomas, and A. V. Kurpad, "Poverty and the state of nutrition in India," Asia Pacific Journal of Clinical Nutrition. 2013, doi: 10.6133/apjcn.2013.22.3.19.

6. R. Ferrão, “Food security in India,” Brazilian Journal of International Law. 2017, doi: 10.5102/rdi.v14i1.4381.

7. M. E. Tusneem, “Agriculture and food security,” in South Asia 2060: Envisioning Regional Futures, 2011.

8. B. D. Souza and K. R. M. Rao, "Challenges in achieving food security in India," Asian J. Microbiol. Biotechnol. Environ. Sci., 2016.

9. I. Ozturk, "Sustainability in the food-energy-water nexus: Evidence from BRICS (Brazil, the Russian Federation, India, China, and South Africa) countries," Energy, 2015, doi: 10.1016/j.energy.2015.09.104.

10. S. Lopez-Ridaura, R. Frelat, M. T. van Wijk, D. Valbuena, T. J. Krupnik, and M. L. Jat, "Climate smart agriculture, farm household typologies and food security: An ex-ante assessment from Eastern India,” Agric. Syst., 2018, doi: 10.1016/j.agsy.2017.09.007.

11. S. Masiero, “Redesigning the Indian Food Security System through E-Governance: The Case of Kerala,” World Dev., 2015, doi: 10.1016/j.worlddev.2014.10.014. 

